\title{
FRONT.OCCIPITAL PHOTOGRAPHING WITH VARIABLE FOCUS X-RAY TUBE ON THE PYRAMIDAL PART OF THE TEMPORAL BONE
}

\author{
By
}

\author{
H. SATO, M. GOTO AND S. KUNIMOTO
}

From the Otolaryngologic Clinic, Muroran Work Hospital Fuji Iron Work Co. Ltd.

Authors constructed the $\mathrm{x}$-ray tube which could reduce the focus to $0.3 \mathrm{x} 0.3 \mathrm{~mm}$ on the pinhole camera.

With such a tube, it was investigated the necessary distance between the focus of the tube and patient for the pyramidal part of the temporal bone to be included in the shadow of the orbital edge.

Owing to the front-occipital photographing with the variable focus $\mathrm{x}$-ray tube, which could be reconstructed at a low cost, it was able to obtain more easily the sharp shadows of the internal ear, pericarotic and peritubal cells which had not been expected with the permanent focus $x$-ray tube used commonly.

\section{側頭骨錐体部 X 線写真における可変微小焦点撮影法と 前頭後頭撮影法の応用について}

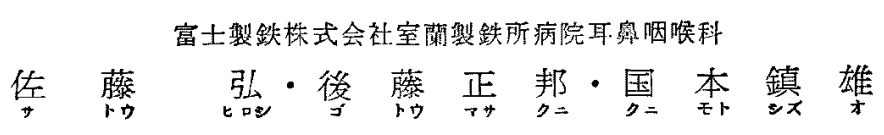

\section{緒論}

側頭骨錐体部はその解剖学的位置の関你より Stenvers, Mayer 並に Schüller 氏法の如き種々なる撮影

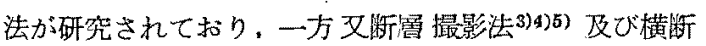
撮影法”等も試られているが後 2 者の方法は装置並に影 像の鮮鋭度の面からな扣広く実用になし難い状態であ る.現在最す広く用いられている Stevers 氏法に沶、 てさえその撮影争度及体位がかなり困難な計りでなく未 た他部位の撮影法程その響影が容易ではない，か」る読 影の困難な由来は，

（1）小部位にして内部構造が複雑なる事.

（2）頭蓋骨は一般に密倿大にして X 線透過晏が低 い事.

（3）目的とする部位がフイルム面に密着せず頭蓋内 梁部仙ある事。

等々に因ると思われる，そこで錐体部 X 線写真の哂影 を従来より容易にするためには，撮影体位の及ならず別 な方面からの検詩が望ましい，中でる訿影条件を支配す る影像の佯鋭度を高める方法を考察すると，
（1）フイルム及び增感紙などの性能の向上

(2) 管球焦点の微小化

（イ）ピンホールを X 線射出口に置く法

(口) 固定微小焦点法

(八) 可变微小焦点法

等の方法分教觉られる。(1) の方法も年々淮歩している

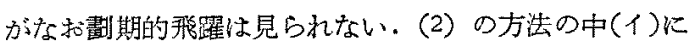
は程々の難点があり(口)も Philipp, Müller 社の如 は $0.3 \times 0.3 \mathrm{~mm}$ の焦点のるのを既に朿貶しており最近本 邦でも製作され始めているがな特との普及化には硅遠 い、しかるに(ハ)の方法について昭和 29 年高橋氏 等 が発表して以来これを直接拉大撮影法にも応用し内利方 面の一部で関心が払われたに抱らず一般化されず耳學咽

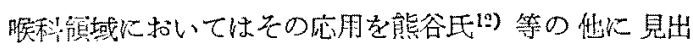
乙得ない，以下高橋氏法を基として其心裝置，撮影条件 並に体位を改良したところ，芫るべき成果淿たので坏 告する。

なお本婑置の改良及び電気的撮影条件は当病院 $\mathrm{X}$ 缐 挍術者古谷鉄雄氏が担当した。 
装置及び撮影条件

第 1 图

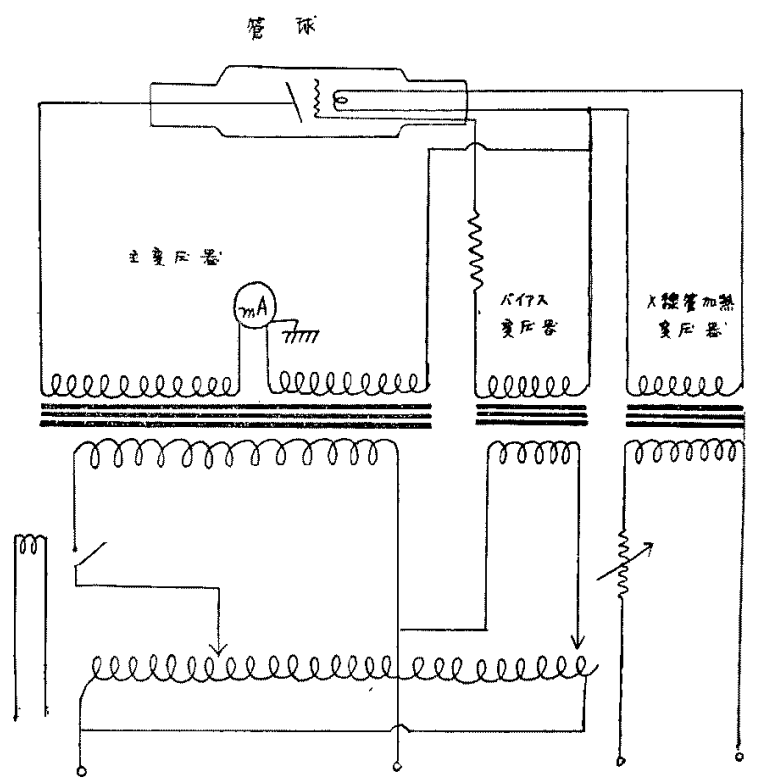

第 2 図 陽極焦点の変化
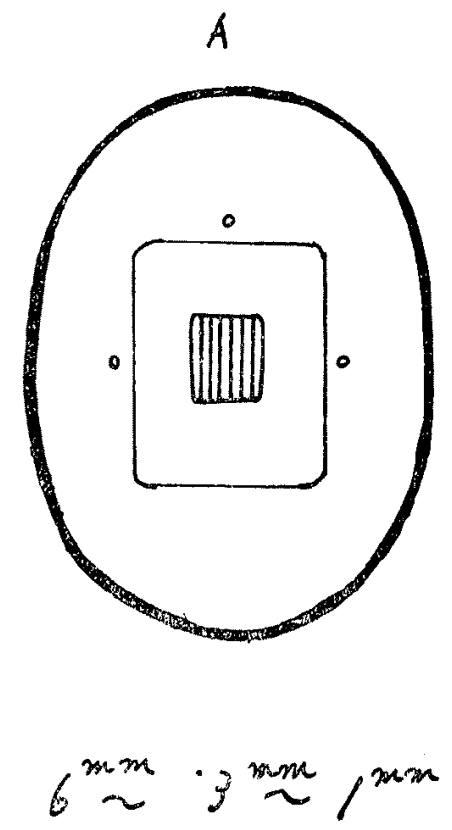

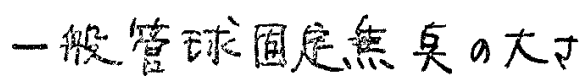

B

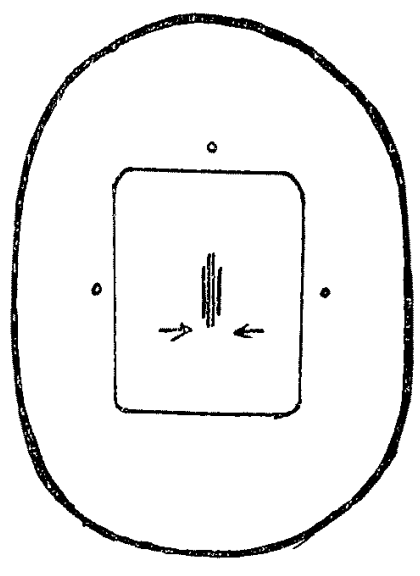

$0.6^{x+m} \sim 0.3^{\mathrm{mm}}$

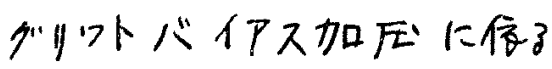

息颅の爱化

位用したX 湶管球恃東芝製 SDWR-6KW\# 5029 で 高橋壬の原著に従い改良した。この管球にグリットパイ フスを次第に負荷し陽極焦点を順次微小化してこれをピ ンホールカメラに撮影寸れば，写真（1）の如くなる.

$\mathrm{X}$ 線発生装置は第 1 図の如く高橋㚤の方法を改良し グリットバイアスを連続的に変化し得る如くした。第 2 図は焦点の変化を示挌图である.かくして常用した焦 点はピンホールカメラによれば $0.3 \times 0.3 \mathrm{~mm}$ 付近で，撮 影条件は密着撮影飞叔いては成人男子で管電圧 70KVP, 管電流 $10 \mathrm{~m} \mathrm{~A}, ク ゙ リ ッ ト$ 電圧 $1250 \mathrm{~V}$ ，管球フイルム問 の距離 $50 \mathrm{~cm}$, 時閒 1.5 秒, 增感紙 $\mathrm{F} \mathrm{S}$ ，シエナンデル リスホルムブレンデ 2 倍直接拉大撮影炕いてては管電 E70KVP，管電流 $10 \mathrm{~mA}$ ，グリット電圧 $1250 \mathrm{~V}$ ，管球 被写体下面間の距離 $50 \mathrm{~cm}$, 管球フイルム間の距離 100 $\mathrm{cm}$, 時間 3 秒, 增感紙パターソン par-speed, さくら〉 イルム等基潐とした。

改造前の本管球は陽怔焦点 $3.0 \times 3.0 \mathrm{~mm}$. 改造瑷の本

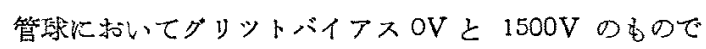
は写真 (2) (2') の如き 2 倍直接扰大の 金絧写真像を呈 さる，即ちグリットパイアスOVにおいては金網の絽線 
はその最も鮮鋭な部分に沏いても認奴られない

な拉本装置とその電気的提影条作の詳細については古 谷氏の原著11を参照されたい。

\section{体位}

前述の罟置による錐体部撮影の体位を検㑏するに，

a） Stenvers 氏法は現今最も広く健用される体位て 錐体長橧はフイルム面と平行になり他の骨像之の重複む 見られない：この点読影炍当つて最大の長所であるが， 体位並びに管球方向を各 1 回しかむ相当正確な補正を要 すると共にこれを左右別々に計 2 回の撮影を行う必要が ある。

b) Schüller ${ }^{8) 10)}$ 氏後頭前頭法は左右を同時に1 枚 のフイルムに撮り得る点は Stenvers 氐法に勝るがその 体位がフイルム面煌面を当てた侑伏せの体位である点 Stenvers 上法之大差なくしか子眼答縁は錐休部よりつ イルム面汇近いためその掘大率は錐体部より少く徉つて

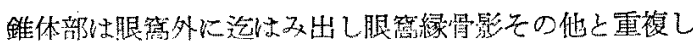
読影を困難にしている．写真 (4)

c）前頭後頭法は前述の後頭前頭法を裏返した体位で フイルム面を枕とした最む自然な仰卧位である。军真 (3)（3）及び第 3 图. 先ず管球焦点を休軸中央に合せ ると共に盆根部付近に迄持ちきたし，次に正しい側面か ら見た場合，焦点と外耳道孔を結ら線が活ぶ腿筬外縁中 央を通る如く軽く下顎を引かせるとよい，

以上言葉で述べると大変なようであるがこの体位は他 浩に比較し最も簢単であると共に最も楽な体位である。

可変微小焦点撮影法の目下の最大の短所性 X 線の暴

第3 图管球被写体及びフイルム間の関俰

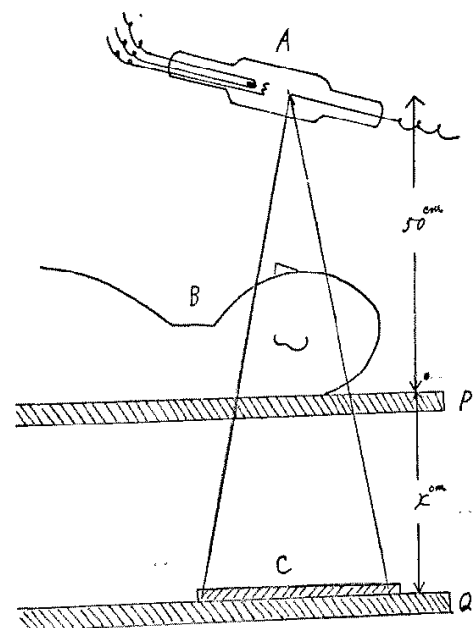

射時閆の長い、馬であるが本体位が安定なためこれは余り 間睤とはならない．著者は最長 20 秒の暴射においてる な和解鋭なる像を得た。

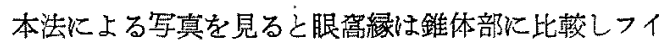
ルム面から離れているので錐体影像より搪大され錐体影 像は楽に眼简縁内に包括されるため他の骨影と重復する 禁なく諘影は容易である 写真 (5) (6) (7) (7') (8) (9). 本体位を Stenvers 氏法々比較する時錐体部が フイ ルム面と約 45 度の角度を持つため，錐体像がや小短縮 されて投影される点が短所であるがその他の点に関して は Stenvers 氏法よりも簡易にしてしか子安定せる体 位であつてこれを可変微小焦点法と組合せる事により， 従来の錐体部写真に比して偍秀な結果が得られる。(後 述兓影法《詳还する.)

本体位を用いる撮影法は他の目的にも使用されてお

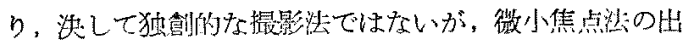

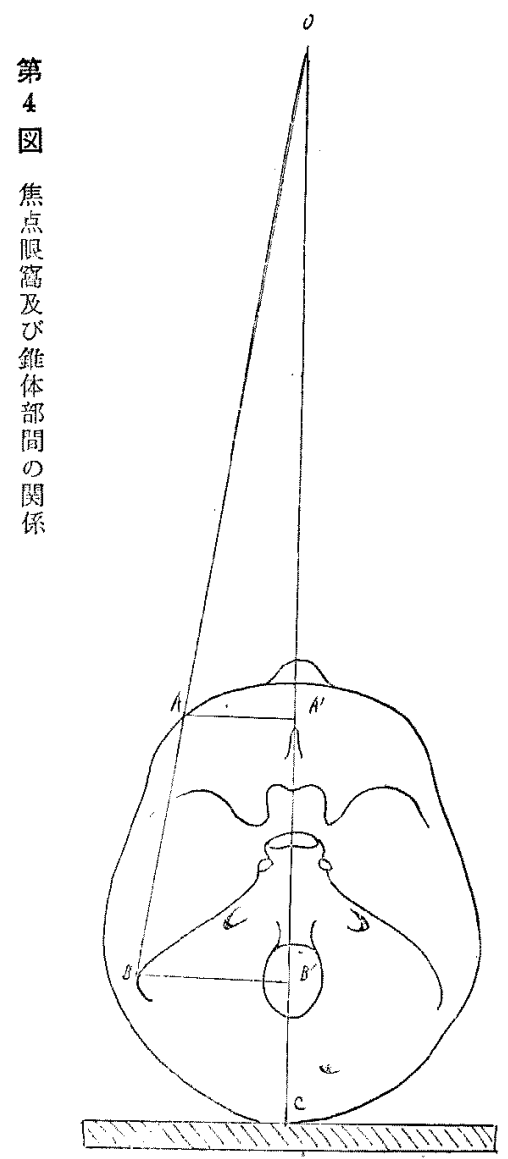



前頭後听拫影法の空用について

現により，侧暊骨撮影に和いて新な意略を持つてきた訳 である.

\section{焦点被写体間の距離の検討}

前述の前頭後頭法における焦点被写体下面間の距離に つ、て検討するに，今 1 例の彉蓋骨を取り，第 4 図の如 く前頭後頭撮影法の位置で, フイルム面上に置さ，腿䒫 外縁 A 及び錐体媵上棱外縁 B より正中矢状面一垂線 を下し，その交点をそれぞれ $\mathrm{A}^{\prime}$ 及び $\mathrm{B}^{\prime}$ とする。

$\mathrm{A}^{\prime} \mathrm{B}^{\prime}$ を延長し，フイルム面と交わる点を C, A BD 延長々交わる点を $\mathrm{O}$ とすれば，OC は錐体長軸力腿登 内に丁度納まる焦点被写体下面間距稚という憘になる。 即る読影に適当な OC を見出すためには，頭蓋骨を計 湘し、これに推計学的検討を加えた值を取ればよい。

著者は札帨医大山崎孝公の御好意により，男子成人頭 蓋骨 16 個，女子·成人頭蓋骨 11 個について $\mathrm{AA}^{\prime}, \mathrm{BB}^{\prime}$, $\mathrm{A}^{\prime} \mathrm{B}^{\prime}, \mathrm{B}^{\prime} \mathrm{C}$ を計湘し, OC の総平圴を求めた所 $78.5 \mathrm{~cm}$ となつた，又その標焦偏差は，29.7cm となつたためOC

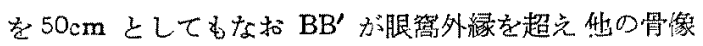
と重複する碩度は，16\%以内に此まる事が判明した。

次に撮影时の暴射時間の点から考えると, 笔圧を一定 にする限り暴射侍間は焦点, フイルム間の距離の二乗に 反比例するため，管球はフイルム面に近い程有利であ る.しかし乍ら一方管球フイルム間の距離を近づけるに 徒い，中心放線から離孔るに比例してフイルム面の影像 は不鮮明となる事は采纳の通りで走来の大焦点管球では 特に鼠著である.著者の使用した $0.3 \times 0.3 \mathrm{~mm}$ 程焚の焦

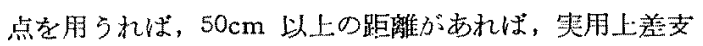
えない事は前述金細写票上り推定される。

以上から焦点, フイルム間（焦点, 被写体下面間）の 距離を $50 \mathrm{~cm}$ とし，これを常用した。

な扣直接层大撮影時の条件は，第3図によつて談明す れ圭，PQ間の距離 $\mathrm{xcm}$ を随時変化する事以より，求 さる拨大率の写真が得られるが，著者の経験によれば， 1.5 2.5 倍以上の报大は現在の装置ではな和像の不鮮明 は免れない。

\section{読 影 法}

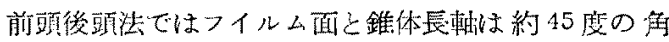

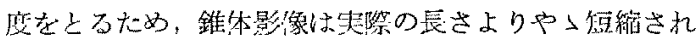
るが，管球焦点が铮来の1/10 以上に微小化されるため， その影像は往来の錐体写真に比較し著しく鮮明である。

写真（7）は被写体の下面に密着撮影せるものであり， 写真 $\left(7^{\prime}\right)$ はその管球フイルム間距離を2借沉した直赛

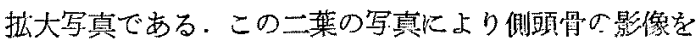

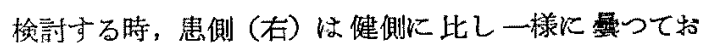
り，乳様蜂霍に主病変のある事は他浩です判明し得る

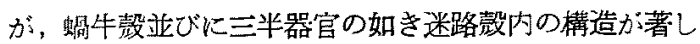
く明瞪である点に注意され舞い。

これを更に具体的に説明すれば螖牛殼像はその頂点を 中心として明膫な渦巻を画き, 又上半器官は錐体稜に向 い半円を面き，水平半器官は第曲部の再脚相重つて投影 されるだめ，根棒状の透逼像として見られる。これ等は 小奣期迄の影像において特に美麗である。

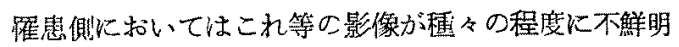
となり，写真 (6) (7) (7')（9）の如き慢性病变に和い ては, 蚟牛豰影の肥厚及び濃化, 水平半器官及び上半器 官像の消失等が見られる.炎症性陰影の種類及びその病 的意義は徒来の撮影法と特に異なるるのでは無いがその 影像が鮮明なため往来法に比し判定が容易である、直接 执大撮影を併用すれは更に院影上有利である。

次に乳様洞入口部上り鼓室迄の影像を見るとSonn-

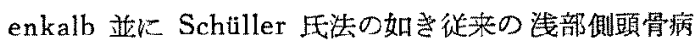
变探求を目的上した撮影法とは角度が約90度移動する ため, 従来法では前後上下の病変の位置判定には便で あつたが本法では病変部の梁浅を判定するに便利であ る.

更に欧氏管周国蜂䆨, 頸動脈管周囲蜂䆵は彷来其の病 変判定が著しく困難であつたが，本法ではこれが可能で ある.これを更に便にするため写真（6）(7)（7'）の如 く造影成を外聴道に注入し，鼓膜及び外聴道の位置を明

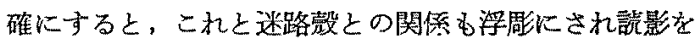
更に容易にする事ができる．写賣 (8) の如く漂白骨の

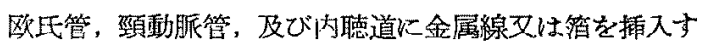
れば欧氏管及び頸動脈管周囲蜂集の位置を゙更に明確に把 握し得る，写真 (6) の如きはその病変が側頭骨全域に 及び，欧氐管周囲蜂贯，頸動脈管周囲蜂䆵迄侵されてい る事を明示する1例である。本例はこれを手術において も確認している。

\section{総括及び考按}

昭和 29 年高橋信次比等に上り 発表された可变微小焦 点撮影法はその結果か㬋秀であると共们高佃な固定微小

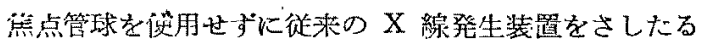
困難もなく本法用に改造して目的を達成し得るにも拘ら ず余り普及していない，

著者の健用した管球第点は前述の如く $0.3 \times 0.3 \mathrm{~mm}$ 程 度のるのであつたが，これを現在洨用されている一般の 管球第点が $6 \times 6 \mathrm{~mm} 3 \times 3 \mathrm{~mm}$ であるのに比較すれば 
俈藤論文付図 (1)

(1)

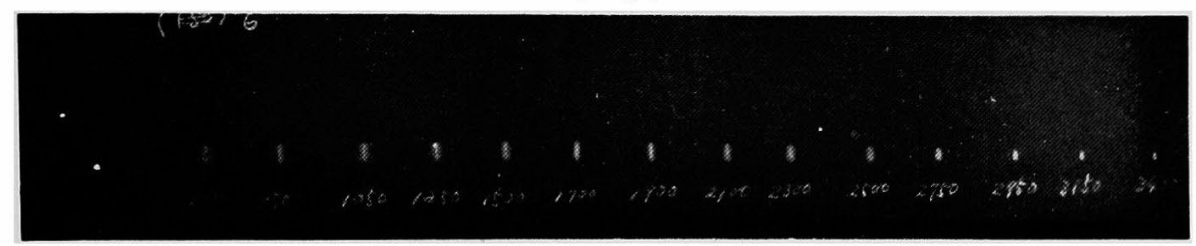

(2)

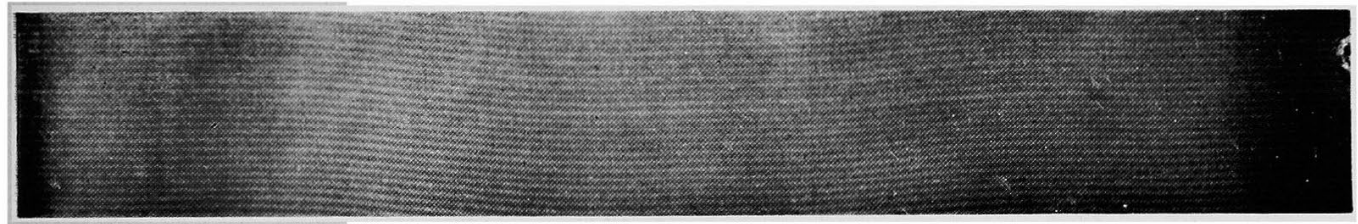

( $\left.2^{\prime}\right)$

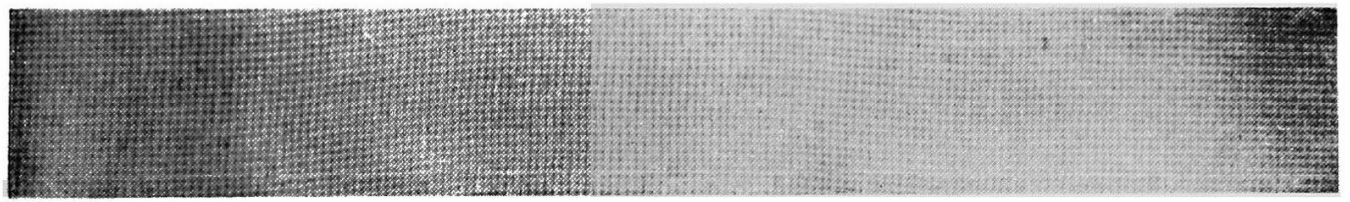

(3)

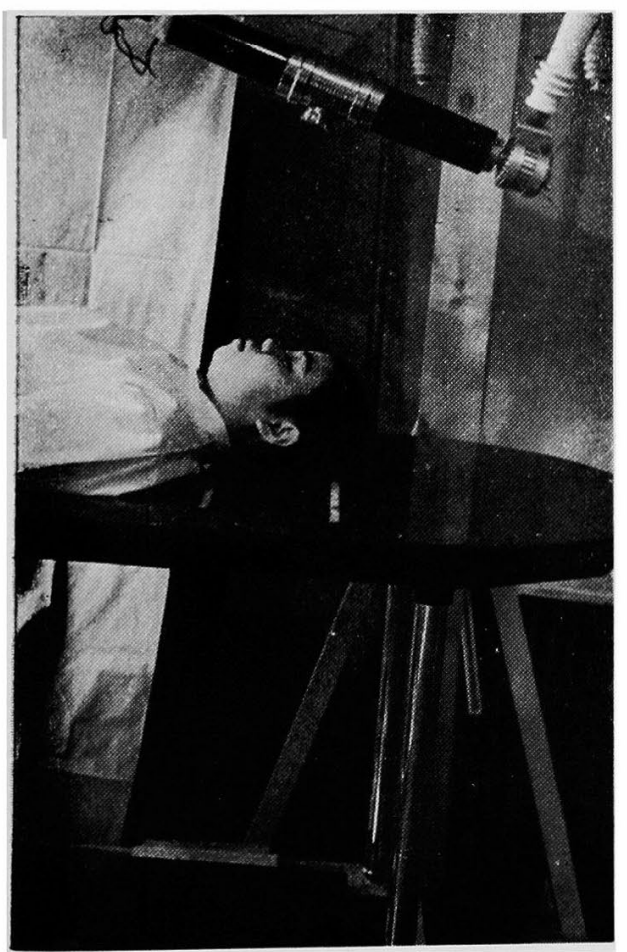

$\left(\mathbf{3}^{\prime}\right)$

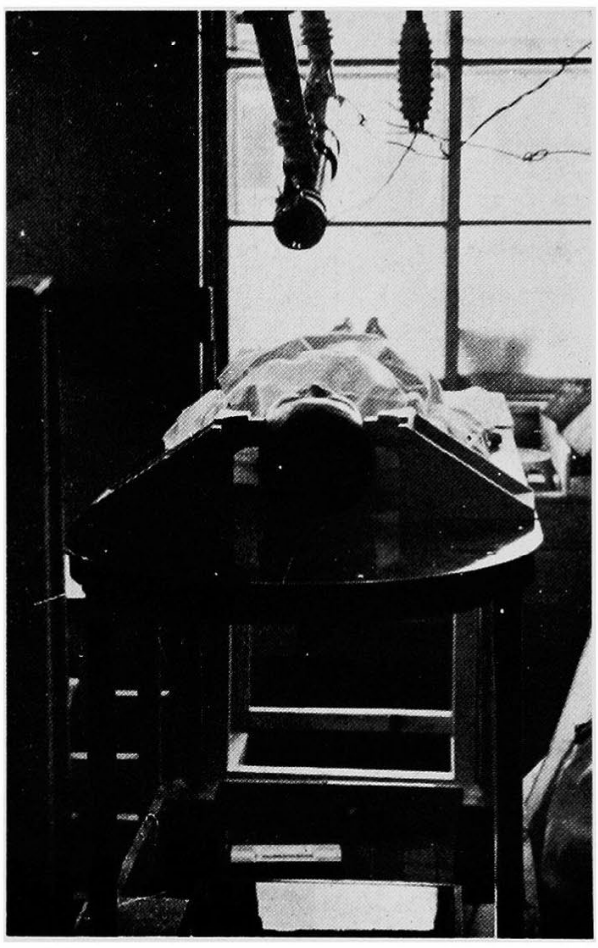




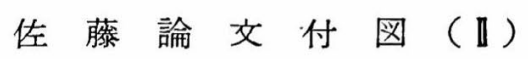

(4)

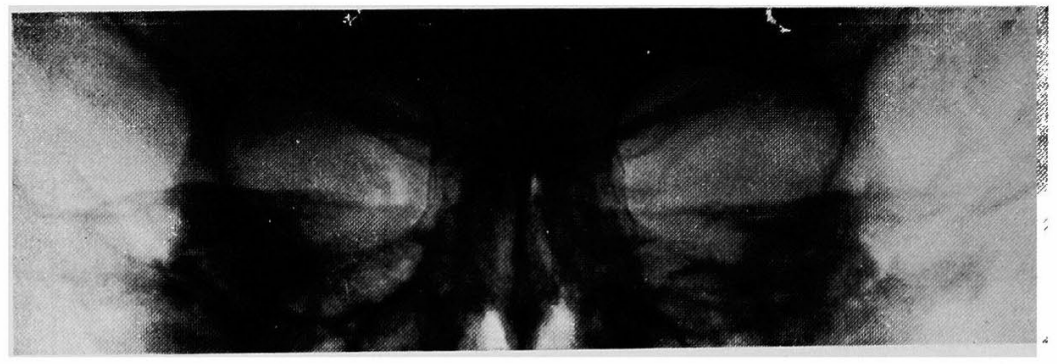

(5)

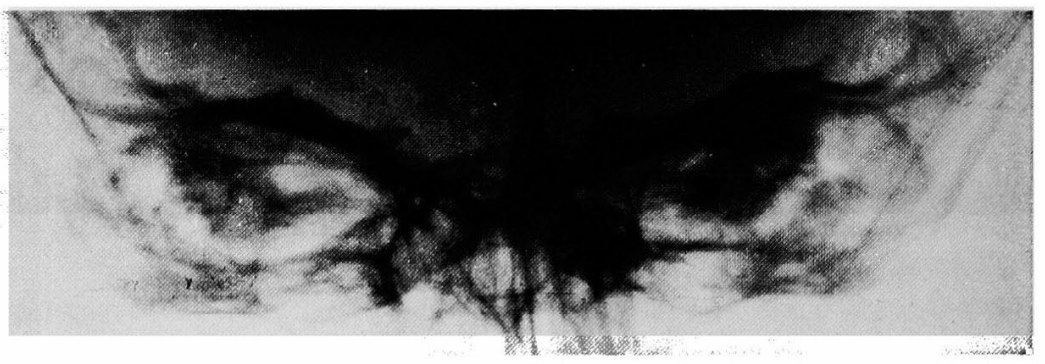

(6)

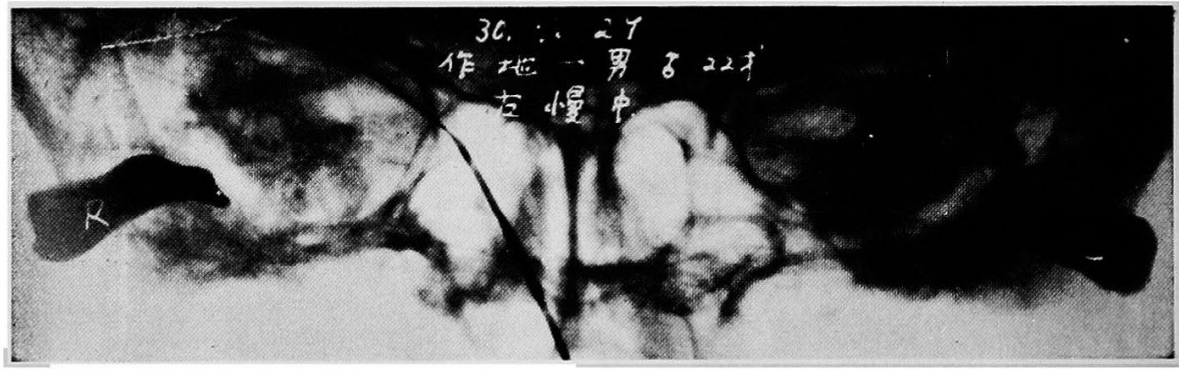

(7)

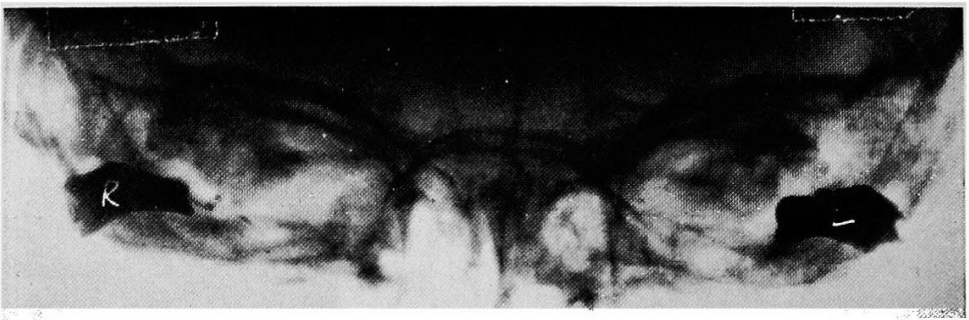

(8)

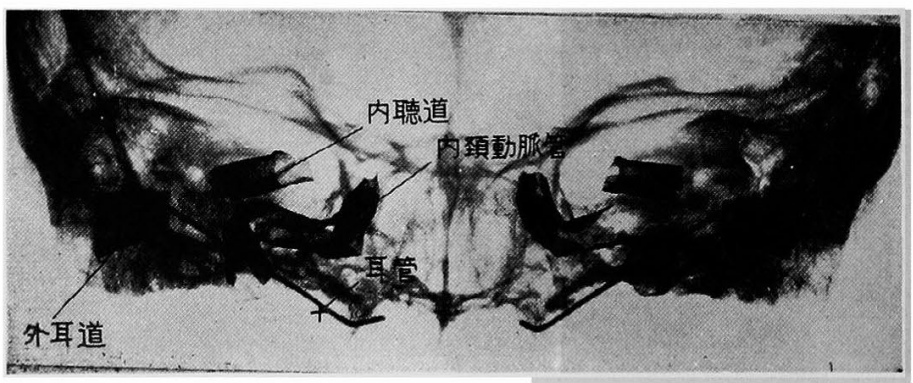




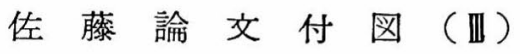
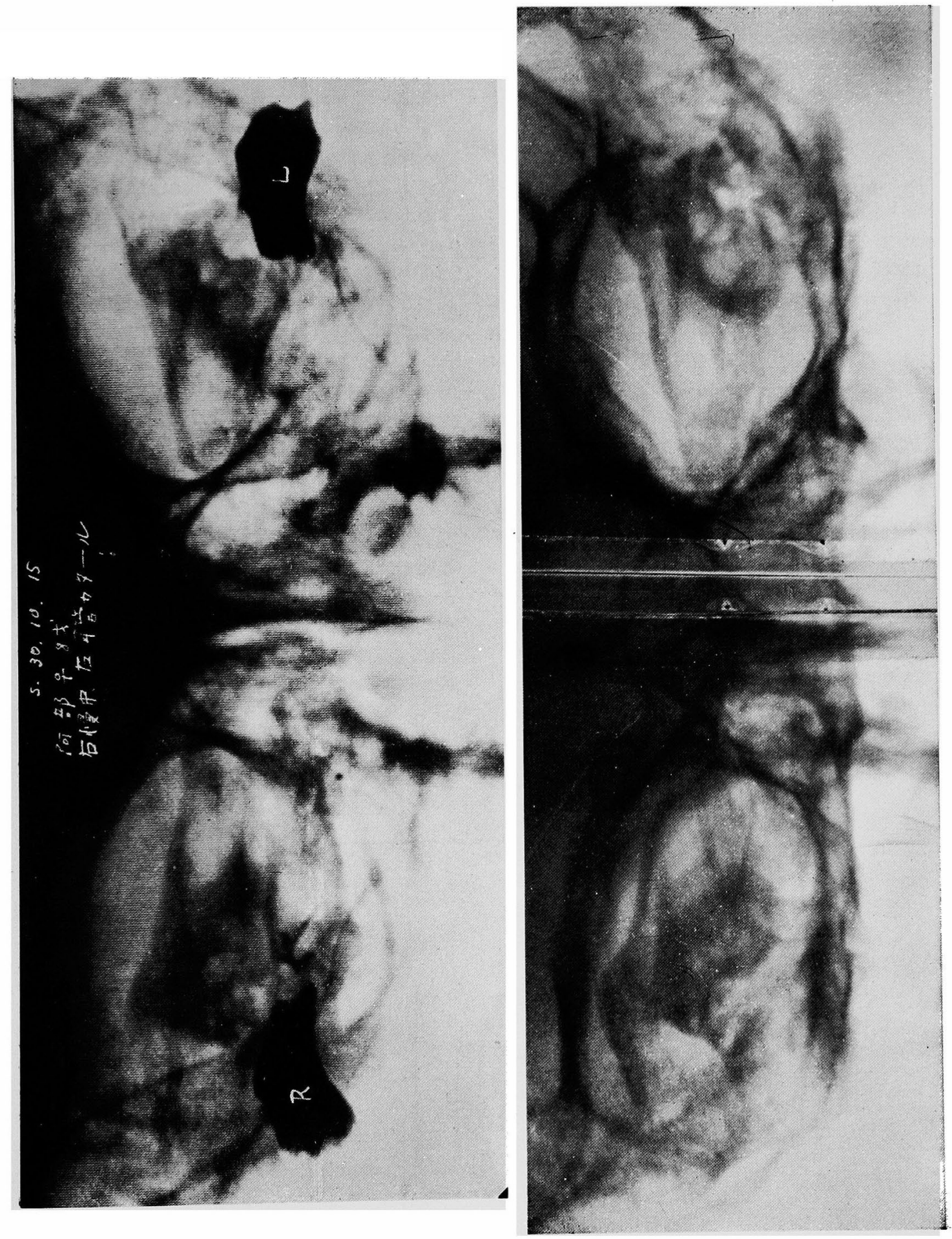

돈 
1/10以下に微小化された事になる。

後滕りはポータブルレントゲン装直により儒秀な耳积 写真を撮影し得ると言つているがこれは管蛷焦点が上述 の大型管球に比龩して $2 \times 2 \mathrm{~mm} \sim 1 \times 1 \mathrm{~mm}$ で可成微小 化されている專がその最も有利な点であつたがかっる小

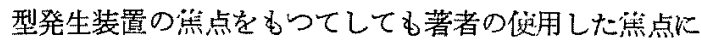
比すれば遥に大である。

又前頭传頭撮影法は従来の大点点管球の优朋によつて は Stenvers 此法程耳和的には甞義を持ち得なからた。 徽小等点法と前䫒後頭法の組合せを面に有効にするた

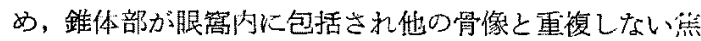

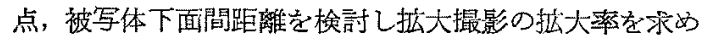
た。

これ等により迷路殼内の状洗が写し出されると共に欧

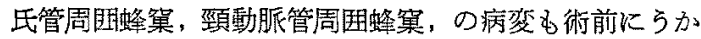
がい知る事ができるようになつた。外聴道に造影削を注 入する力法はこれ等の羦影を更に容易ならしめた。

\section{結諭}

可変深点 X 線撮影法と前頭後頙撮影体位を組合せる 洔に必要な撮影距離を検討しその方法による錐体部 $\mathrm{X}$ 線写真に执いて, 次の如き絬果を得た。

(1) 点点, 被写体下面間の距離は $50 \mathrm{~cm}$ が適当であ る. 直接拉大熶影俚 2.5 倍拡大迄が好結果を得た。

（2）撮影体位が簡易安定である上に 两側を同時に撮 影乙得る。

（3）外聴道に造影威を注入する 牙により，側頭骨内 の各器官の相互の位置的関傒を更に明確に把握し
得大。

（4）蝸牛款三半器官の如き迷路款内の構造及び內㯰 㗐像をらかが、知る事ができる。

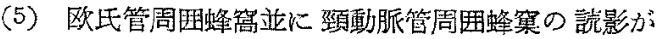
叮能でする。

\section{文献}

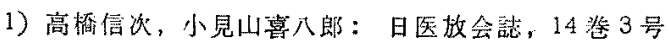
(1954 V1) 2) 吉田三毅夫：日医放会誌，14巻6品 （1954）403. 3) 加藤正明：大日可率会報 48 巻 12 号 4) Alessandro, P.: Estratto da La Radiol gia Media $33 / 9$ 1947, 5) G. Del, Buono: Fortischr, Röntgenstr, $78 / 5$ 1953. 6) 後滕敏郎他: 耳喉科 25 巻 11 号（昭 28）42. 7) 高烟延臣：耳堠科，25巻 9 号 (1953) 27. 8) E. G. Mayer: Otologische Rötngen-diagnostik. 9) Schinz H.R.u. s. a.: Lehrbuch der Röntgen-diagnostik 1952. 10) 高原高三:

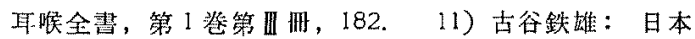
放射線技衍学会，第 11 浩 3 号 12）热谷和夫他：日 耳舆会報, 59 巻 6 号.

本論文の要旨杜札榥に和ける第 57 回日本耳䁷唄 㬋科学会総会に特いて演述した，

な和本撮影法の確立に当り当病院副院長山中博上 の御指尊御援助を得た。ここに記して感謝の意を表 します

（原稆到視二昭和 35.8 .2 日） 